\title{
MINHA CASA, MEU CATIVEIRO - ISOLAMENTO SOCIAL E O AUMENTO DA VIOLÊNCIA DOMÉSTICA EM TEMPOS DE PANDEMIA.
}

Danielle Yurie Moura da Silva, Claudia Primolan de Rezende Dória, Mayara Seriane Ventura Butzske Silva e Romulo Câmara Barleta

Universidade do Oeste Paulista - UNOESTE, Curso de Direito, Presidente Prudente, SP. E-mail: danyurie25@gmail.com

\section{RESUMO}

Desde o nascimento da civilização humana, ao contrário de outros animais, homens e mulheres vivem em um grupo denominado família. Mas, também desde o início, os homens, pela força física e agressividade presentes em seu DNA, alegaram ser o gênero principal, cabendo as mulheres só obedecer. A presente pesquisa envolve o estudo da violência doméstica durante o isolamento social ocasionado pelo COVID-19. O objetivo foi analisar se houve realmente um aumento nos casos de feminicídio por conta do isolamento. A metodologia utilizada foi a qualitativa, por meio da análise hermenêutica de uma série de fatos empíricos e dados disponíveis, com a finalidade de construir uma perspectiva atualizada sobre o tema e corroborar com a narrativa acerca da atual situação da violência doméstica dentro do isolamento social que identificou que essa situação sempre esteve no cotidiano feminino, interpretando as leis e os dados oriundos de pesquisas realizadas por meio de fontes específicas como DataSenado e o Fórum Brasileiro de Segurança Pública. A narrativa, em síntese, defende que ainda existe um hiato entre os direitos garantidos pela Constituição Federal de 1988 para com as mulheres e as práticas institucionais das políticas públicas e do próprio Judiciário. Os resultados evidenciam que existe um longo caminho a ser percorrido para que haja uma mudança significativa deste cenário. Assim pode-se concluir que para que haja uma mudança neste cenário é preciso ocorrer uma desnaturalização da sociedade através de uma educação libertadora que se compromete em erradicar a Violência Doméstica da nossa realidade.

Palavras-chaves: Violência Doméstica. Isolamento Social. Direitos da Mulher. COVID-19

\section{MY HOUSE, MY CAPTIVITY - SOCIAL ISOLATION AND THE INCREASE IN DOMESTIC VIOLENCE IN PANDEMIC TIMES.}

\begin{abstract}
Since the birth of human civilization, unlike other animals, men and women have lived in a group called the family. But, also from the beginning, men, due to the physical strength and aggressiveness present in their DNA, claimed to be the main gender, with women only obeying. This research involves the study of domestic violence during social isolation caused by COVID-19. The objective was to analyze whether there was an increase in cases of femicide due to isolation. The methodology used was qualitative, through the hermeneutic analysis of a series of empirical facts and available data, in order to build an updated perspective on the theme and corroborate the narrative about the current situation of domestic violence within the social isolation that identified that this situation has always been in the female daily life, interpreting the laws and data from research carried out through specific sources such as DataSenado and the Brazilian Forum on Public Security. The narrative, in summary, argues that there is still a gap between the rights guaranteed by the Federal Constitution of 1988 to women and the institutional practices of public policies and the Judiciary itself. The results show that there is a long way to go before there is a significant change in this scenario. Thus it can be concluded that for there to be a change in this scenario, it is necessary to occur a denaturalization of society through a liberating education that is committed to eradicate Domestic Violence from our reality.
\end{abstract}

Keywords: Domestic Violence. Social Isolation. Women Rights. COVID-19. 


\section{INTRODUÇÃO}

A presente pesquisa busca analisar a violência doméstica durante $o$ isolamento social, objetivando analisar se realmente ocorreu o aumento de casos de feminicídio por conta do isolamento proveniente da pandemia resultante do COVID-19.

Antes mesmo do Coronavírus surgir e impactar o mundo, outras patologias como Herpes, AIDS, Ebola, Síndrome Respiratória Aguda Grave (SARS), Síndrome Respiratória do Oriente Médio (MERS-COV) já foram vistas, entretanto o cenário mundial é um caos, não apenas na saúde, mas afetou também inúmeros setores tais como o econômico, educacional e até o familiar (VALENTIN et al., 2019; ARSHAD et al., 2020; JONES, 2020).

Diante disso, o COVID-19 têm sido objeto de discussão no mundo todo, mobilizando cientistas, médicos, juristas e a população em geral, e especialmente no Brasil, onde Presidente da República desconsidera as recomendações da Organização Mundial da Saúde (OMS), mantendo um discurso que divide as opiniões e a população. Em meio à crise, a pasta de dois ministros da saúde mudou, e o cargo ficou vago mais de um mês, dificultando a ação coordenada entre as filiadas, tornando o Brasil um dos países mais infectados e afetados.

Por este motivo, esta pesquisa se propõe a expor os índices de violência contra mulher, evidenciando principalmente o contexto da pandemia, tentando demonstrar seus impactos e que ainda não foram totalmente dimensionados.

O isolamento social foi uma medida encontrada pela OMS visando proteger a vida humana, porém em contra partida acabou evidenciando um problema ainda maior. Isso porque por esse motivo, muitas mulheres acabaram tendo que conviver por um período muito maior com os seus agressores conforme dados apresentados pelo Observatório da Mulher contra a Violência (OMV).

Assim o isolamento acabou trazendo à tona, e ainda de forma otimizada, alguns indicadores alarmantes sobre a violência doméstica, se fazendo necessário refletir sobre esse assunto, e mostrando como as produções acadêmicas podem contribuir no combate a esse tipo de violência.

É notório que o COVID-19 é a mais grave emergência de saúde já enfrentada nos últimos tempos, e por isso o objetivo da presente pesquisa é demonstrar, iniciando do estudo histórico por meio de bibliografias, pela análise dos fatos e dados por meio do método dedutivo afim de tentar expor esse problema e apresentar possíveis soluções.

\section{MÉTODOS}

A metodologia utilizada foi a qualitativa, por meio da análise hermenêutica de uma série de fatos empíricos e dados disponíveis, com a finalidade de construir uma perspectiva atualizada sobre o tema e corroborar com a narrativa acerca da atual situação da violência doméstica dentro do isolamento social que identificou que essa situação sempre esteve no cotidiano feminino, interpretando as leis e os dados oriundos de pesquisas realizadas por meio de fontes específicas como DataSenado e o Fórum Brasileiro de Segurança Pública.

A narrativa, em síntese, defende que ainda existe um hiato entre os direitos garantidos pela Constituição Federal de 1988 para com as mulheres e as práticas institucionais das políticas públicas e do próprio Judiciário.

Desta maneira, os resultados evidenciam que ainda há um longo caminho a percorrer até que grandes mudanças ocorram nessa situação, não apenas por meio de leis que adotam penas mais severas, mas também por meio da degeneração social que só pode ser alcançada por meio da educação liberal para que haja a eliminação da violência doméstica da realidade da mulher.

\section{A intervenção histórico-jurídica contra a Violência Doméstica}

Os primeiros registros de violência doméstica atravessam os séculos da civilização humana, embora haja relatos de submissão feminina muito antes de se haver leis específicas que assegurariam a punibilidade do agressor (CARNEIRO; FRAGA,2012)

A violência doméstica contra a mulher data historicamente no direito Sumério, onde a mulher era um produto de venda e o marido, que a comprara tinha total poder sobre ela, inclusive direito de tirar-Ihe sua vida publicamente em casos específicos (SANTIAGO, 2007).

Ao longo de toda a história da humanidade, embora a sociedade tenha se modernizado, a mulher obteve pouca enfatização nos méritos desses resultados, mesmo que a sua 
participação para a modernidade que vivemos tenha sido essencial.

No Brasil, o Código Penal (CP) de 1890, trazia em seu artigo 27 §4으, a imputabilidade aos que cometiam crime sob completa privação de sentidos e de inteligência no ato criminoso, o que agregava junto ao rol dos inimputáveis, os parceiros que por violenta emoção agrediam e até mesmo assassinavam suas parceiras, sendo classificado como um crime de paixão, os ditos crimes passionais, a lei dava guarida para que homens que se sentiam de alguma maneira desmoralizados ou enciumados, cometessem a bárbara agressão sem que fossem condenados a algum tipo penal (GOMES, 2013).

Durante todo o século seguinte, era comum e até mesmo normal nos noticiários do nosso país, reportagens que expressavam a violência doméstica como um ato bárbaro, porém por aspectos de uma sociedade machista, eram totalmente ignorados, muitas vezes até mesmo minimizados pela sociedade e autoridades de polícia (SILVA, 2010)

O Código Penal de 1940 tipificou penalmente o crime passional não como uma excludente, mas como uma causa de diminuição do artigo $121 \mathrm{CP}$. Uma grande evolução, pois agora, mesmo que com uma pena menor, havia uma pena.

Em 1983 a Brasileira Maria da Penha foi vítima por duas vezes de tentativa de homicídio pelo próprio companheiro, a primeira tentativa resultou na perda da sua capacidade motora, restando paraplégica, a segunda tentativa, de forma mais grotesca, o mesmo agressor, tentou eletrocutá-la (LIMA, 2018).

Embora restou condenado diversas vezes pelas tentativas citadas anteriormente, Marco Antônio Herredia Viveiros nunca foi preso. Indignada com a lentidão processual Maria da Penha levou o caso à Comissão Interamericana de Direitos Humanos, uma vez que o Brasil é signatário do Pacto de San José da Costa Rica, inclusive se sujeita à jurisdição da Corte Interamericana de Direitos (LIMA, 2018)

No ano de 2001 depois de vasta luta jurídica a Organização dos Estados Interamericanos (OEA), imputou ao Brasil a responsabilidade por negligência e omissão nos casos de violência doméstica em solo brasileiro. Após a repercussão internacional do caso de violência doméstica de Maria da Penha, o Brasil foi forçado a elaborar medidas punitivas direcionadas a esse crime, surgindo então a Lei no
11.340, cuja homenagem carrega o nome da Vítima Maria da Penha.

O agressor foi preso no ano de 2003, após o processo ser definitivamente encerrado. Frisa-se que os danos causados pela violência doméstica contra Maria da Penha foram irreversíveis, hoje esta conta com 75 anos e seu caso encoraja mulheres no mundo todo a denunciar agressores dessa espécie.

O Pacto de San José da Costa Rica, prevê em seu artigo 28 que em se tratando de uma República Federativa, responde então o Governo na esfera internacional pelos crimes praticados pelos agentes que compõem a federação (BRASIL, 1992).

O direito Internacional precisou intervir no Ordenamento Jurídico Brasileiro, a fim de responsabilizar os agentes causadores, bem como dar o mínimo de amparo legal as vítimas que buscam nada além da almejada Justiça.

Mesmo com o advento da Lei 11.340, a Lei "Maria da Penha", os casos de violência doméstica ainda figuram como um dos crimes que mais assolam o solo pátrio. Isso nos leva a questionar a eficácia da norma jurídica em questão (LIMA, 2018)

Se, mesmo após uma condenação pela Corte Interamericana de Direitos Humanos, o Estado Brasileiro não foi capaz de controlar o problema da violência doméstica, talvez tenha passado da hora de a Corte intervir novamente, vez que claramente as penas ainda são brandas, visto que não coíbem a prática do delito.

\section{0 isolamento social causado pelo covid-19 e seus reflexos - Dados da violência no Estado de São Paulo.}

Na virada do ano o brasileiro com sua pluralidade de crenças, ideologias e valores, pede que o ano que está por vir seja infinitamente melhor que aquele que passou; pula sete ondas intercalando seus desejos; come romã e guarda as sementes na carteira na esperança de tê-la sempre recheada; veste roupa branca desejando a paz, entre tantos outros sortilégios. Pede a Deus, aos deuses, aos Orixás, afinal de contas o Brasil é um Estado Laico em virtude de dispositivos constitucionais que amparam a liberdade de religião.

É preciso, porém, reconhecer que apesar de todas as orações, pedidos e sortilégios de um ano melhor, 2020 iniciou diferente, pois no final do ano de 2019 a Organização Mundial da Saúde (OMS), já havia divulgado que na cidade de 
Wuhan, autoridades chinesas notificaram casos de uma pneumonia que se alastrou a uma velocidade inexplicável, fazendo com que fossem tomadas medidas de isolamento e exames nos infectados para apontar a origem da doença. Logo descobriu-se que a doença covid-19 causada pelo coronavírus, denominado SARS-CoV-2, seguia transmitindo o vírus de pessoa a pessoa e matando milhares ao redor do mundo. (BRASIL, 2020b).

Entretanto, o que temíamos ocorreu, o "coronavírus" rompeu as barreiras e foi responsável pela pandemia atual de covid-19, alastrou-se, infectando e matando milhares de pessoas ao redor do mundo.

O Ministério da Saúde (OPAS BRASIL, 2020) informou que o coronavírus chegou ao Brasil em 26 de fevereiro de 2020, após a confirmação de que um homem de 61 anos, da cidade de São Paulo, retornando da Itália, testou positivo para covid-19.

No Brasil estima-se que até o final do segundo semestre de 2020, o coronavírus causará a morte de aproximadamente $180 \mathrm{mil}$ brasileiros em uma curva crescente, essa previsão é do Instituto de Métrica Avaliação em Saúde (IHME, 2020), da Universidade de Washington.

Segundo Murray (2020, apud Duarte, 2020): O Brasil deve seguir a liderança de Wuhan, China, bem como a Itália, a Espanha e Nova York, impondo mandatos e medidas para obter o controle de uma epidemia em rápida evolução e reduzir a transmissão do coronavírus.

Entre as várias medidas de enfrentamento do coronavírus, o isolamento total foi reconhecido universalmente como medida mais eficaz de combate aos avanços do covid-19, porém percebe-se que o isolamento imposto vem acarretando inúmeros problemas sociais, econômicos, políticos, culturais, sem precedentes na história da humanidade.

Muitas pessoas durante $\mathrm{o}$ isolamento têm sofrido com ansiedade, depressão, desemprego, crises financeiras entre outros males. Inclusive experiências mundiais têm mostrado que houve o aumento da violência doméstica, devido as tensões ocorridas dentre dos lares, pois o que obriga as mulheres a conviverem 24 horas por dia, durante 7 dias da semana, com os seus agressores, tornando-as ainda mais vulneráveis.

$\begin{array}{lcc}\text { Segundo } & \text { a } & \text { ONU } \\ \text { Mulheres } & (2020, & \text { apud }\end{array}$

TOKARSKI, ALVES,
2020):
O aumento dos riscos da
violência doméstica, em
contextos como o atual,
acontece devido ao
aumento das tensões
dentro de casa, já que
mulheres em
relacionamentos abusivos
e violentos em isolamento
social ficam expostas ao
seu abusador por longos
períodos de tempo, o que
dificulta ligações
telefônicas para disque-
denúncias ou para a
polícia, uma vez que o
abusador está sempre por
perto.

A agressão, em âmbito familiar, é um crime praticado predominantemente dentro das residências, podendo ter como autores o marido, o companheiro, um ex-parceiro, o namorado, o filho ou o pai. No entanto, os principais agressores são o marido e o ex-parceiro, pessoas com as quais a mulher construiu laços de confiança e afeto.

Por muitos anos a sociedade negligenciou esse pedido de socorro, gritando em alto e bom som, "Em briga de marido e mulher, ninguém mete a colher". No entanto, o fato de uma mulher querer igualdade e tomar suas próprias decisões não pode nunca justificar a violência e Santos (2003) evidencia isso:

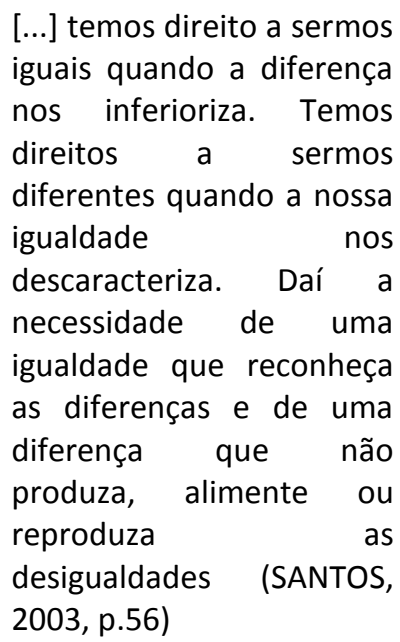

Quando não há ação, quando o silêncio reina, nos tornamos cúmplices da perpetuação da violência contra as mulheres que culmina em mortes. Culturalmente o povo brasileiro ainda é patriarcal e machista, trata as mulheres como 
objetos, desejando ter controle sobre suas vidas e corpos.

Segundo Blay (2014, p.16), "a violência contra as mulheres - simplesmente porque são mulheres - tem uma complexa fundamentação em valores patriarcais. É base para manutenção do exercício do poder e se instrumentaliza através de relações de dominação e subordinação"

A vida sem violência é um direito. Nesse sentido a Constituição Federal (BRASIL, 1988) em seu artigo 226, parágrafo 8 o, estabelece que 0 "Estado assegurará a assistência à família na pessoa de cada um dos que a integram, criando mecanismos para coibir a violência no âmbito de suas relações". Referido dispositivo zela pela proteção da mulher que sofre violência doméstica. Portanto, como já mencionado, as mulheres têm o direito de viver livres de violência e de discriminação e o direito de serem valorizadas.

É inconcebível que em pleno século XXI mulheres ainda tenham que conviver com frases do tipo: "não sei porque bati, mas ela sabe porque apanhou", "ele é um bom marido, mas quando bebe..." ou "a mulher que mostra o corpo merece ser atacada", como se a culpa por apanhar, por ser violentada fosse das vítimas e não dos agressores. Uma sociedade que condena mais a roupa da mulher do que a agressão de um marido não é uma sociedade sadia. É importante promover ações para mudanças culturais e sociais.

Os índices de violência no Brasil vêm sendo monitorados através do Atlas da Violência, produzido pelo Instituto de Pesquisa e Econômica Aplicada (IPEA) e pelo Fórum Brasileiro de Segurança Pública (FBSP) para uma melhor compreensão do processo acentuado da violência no país e a cada dia, fica mais evidente que mesmo antes da chegada deste vírus outras patologias já existiam entre nós (INSTITUTO DE PESQUISA ECONÔMICA APLICADA,2019).

Os dados levantados indicam que a violência é uma variável presente no cotidiano das mulheres brasileiras e que superá-la envolve não só o acolhimento da vítima, o acesso à justiça e a punição do agressor, mas também estratégias de prevenção que trabalhem a origem de todas essas diferentes manifestações de violência.

A segunda edição da pesquisa "Visível e Invisível: a vitimização de mulheres no Brasil", realizada em 2019 pelo FBSP e Data Folha
Instituto de Pesquisas (FÓRUM BRASILEIRO DE SEGURANÇA PUBLICA, 2019), revelou que:

A maioria das mulheres continua sendo vítima de violência dentro de casa (42\%), e apenas $10 \%$ relatam ter buscado uma delegacia da mulher após o episódio mais grave de violência sofrida no último ano. Infelizmente $52 \%$ das mulheres alegam não ter feito nada, mesmo percentual da pesquisa realizada dois anos antes, na evidência do desafio posto para a proteção das mulheres em situação de violência.

No início do período pandêmico, mais especificamente logo após as medidas de isolamento social decretadas no país, foi realizado um estudo que compila dados sobre a violência doméstica com o objetivo de compreender o impacto que essa medida poderia estar causando. Esse estudo foi elaborado pelo FBSP a pedido do Banco Mundial, em forma de uma nota técnica denominada Violência Doméstica durante a Pandemia de Covid-19 - Ed. 2a (FÓRUM BRASILEIRO DE SEGURANÇA PÚBLICA - FBSP, 2020), na qual foi possível observar uma redução dos registros de lesão corporal no Estado de São Paulo, de 21,8\% entre 2019 e 2020, nos meses de março e abril dos respectivos anos. Constatou-se também esse padrão em outros estados da Federação que compuseram a pesquisa, demonstrando uma queda média de março e abril de 2020 em relação ao mesmo período de 2019 , de $25,5 \%$, o que coincide com dados da Itália e cidades dos EUA. Presume-se que essa diminuição é explicável pelo simples fato de muitas mulheres não estarem conseguindo sair de casa para fazer a denúncia, seja por medo de contrair o vírus ou pela presença constante do seu algoz.

Outro elemento importante trazido pela pesquisa são os casos de feminicídio que tiveram um crescimento de 22,2\%, isso nos 12 estados analisados, saltando de 117 vítimas em março/abril de 2019 para 143 vítimas no mesmo período de 2020. No Estado de São Paulo o crescimento também foi acentuado. Os casos de feminicídio aumentaram em torno de $41,4 \%$ nos meses de março e abril de 2020, ante o mesmo 
período de 2019 (FÓRUM BRASILEIRO DE SEGURANÇA PÚBLICA, 2020)

Percebe-se que a violência se manifesta de diversas formas, não é isolada e nem esporádica, pelo contrário, é recorrente, segue um ciclo crescente socialmente tolerada e escondida pela vítima em nome da sagrada família. Uma verdadeira violação dos direitos das mulheres.

É importante saber identificar as três fases distintas do ciclo da violência doméstica na primeira fase ocorre o aumento da tensão, humilhações e ameaças fazem parte desta fase, já na segunda os atos se materializam em violências físicas, sexuais, etc. A terceira fase se inicia, conhecida como "lua de mel" um período de arrependimento e perdão até uma nova agressão, o ciclo se repete com perdão por parte da agredida. (IMP, 2009).

A violência doméstica é uma realidade que assombra as mulheres, mesmo antes da pandemia do coronavírus, a situação já era grave como mostra os dados divulgados pelo Instituto Igarapé, no período entre 2010 e 2017 foram notificados 1,23 milhões de casos de violência no Brasil. Mesmo após a criação da Lei Maria da Penha mulheres precisam diariamente reafirmarem seus direitos, que por muitos são negligenciadas. Educar meninos não resolverá o problema na integra, é necessária a capacitação das mulheres a fim de manter a sua dignidade alta o suficiente para buscarem justiça. (INSTITUTO IGARAPÉ, 2019)

A minimização da violência depende do engajamento e comprometimento de todos os setores da sociedade e de políticas públicas, dentre outros fatores. Esse também é o entendimento desenvolvido por Leite (2001) de que "mulheres e homens podem desfrutar o mesmo espaço com respeito, consideração, dignidade e admiração, sem domínio e subordinação, porque onde há amor não há espaço para hierarquias infundadas, nem ordens sem sentido". Reconhecer, proteger e defender as diferenças, independentemente do sexo, estendendo os direitos a todos, são práticas essenciais para construção de uma nação fraterna e igualitária que reverencie o respeito de uns para com os outros, afinal, somos todos iguais.

Redes de Proteção, como enfrentar à violência doméstica.
Em 2003, um novo olhar se voltou em favor das mulheres, foi criada a Secretaria Nacional de Políticas para as Mulheres (SNPM), com objetivo de promover a igualdade entre homens e mulheres e combater todas as formas de preconceito e discriminação, com radar voltado na construção de um Brasil mais justo, igualitário e democrático, com foco na valorização da mulher e de sua inclusão no processo de desenvolvimento social, econômico, político e cultural do País.

A promulgação da Lei 11.340/2006, popularmente conhecida como Lei Maria da Penha (BRASIL, 2006) e a criação, em 2005, da Central de Atendimento à Mulher - Ligue 180, foram conquistas importantes ao longo dos anos para o fortalecimento da rede de enfrentamento à violência contra as mulheres e da rede de atendimento às mulheres em situação de violência.

Conforme relata:

A Lei Maria da Penha prevê, como uma das estratégias de enfrentamento à violência doméstica e familiar contra a mulher, que "a assistência à mulher em situação de violência doméstica e familiar será prestada de forma articulada e conforme os princípios e as diretrizes previstos na Lei Orgânica da Assistência Social, no Sistema Único de Saúde, no Sistema Único de Segurança Pública, entre outras normas e políticas públicas de proteção, e emergencialmente quando for o caso" (Art. 9o). Além disso, a Lei estabelece a criação de serviços especializados no atendimento dos casos de violência doméstica e familiar contra a mulher, tais como: centros de referência de atendimento à mulher; casasabrigo/serviços de abrigamento; núcleos de defensoria pública; serviços de saúde e centros de perícia médicolegal especializados; 
centros de educação e reabilitação dos agressores centros de responsabilização e educação dos agressores (todos previstos no art. 35) e juizados de violência doméstica e familiar contra a mulher (art. 29) (BRASIL, 2011, p. 10 e 11)

A Lei Maria da Penha, surgiu em 2006, como um instrumento legal de combate a violência doméstica, trazendo para $\mathrm{o}$ ordenamento jurídico brasileiro inovações e providencias legais na afirmação dos direitos humanos das mulheres.

Neste sentido:

A Central de Atendimento à Mulher - Ligue 180, por sua vez, foi criada em 2005, pela SPM, com o objetivo de orientar as mulheres em situação de violência sobre seus direitos e sobre os serviços disponíveis para o atendimento de suas demandas. A Central é um número de utilidade pública, que pode ser acessado gratuitamente por mulheres de todo o país e representa, portanto, um importante avanço no tocante à divulgação dos serviços da rede de atendimento e à garantia de acesso das mulheres à rede (BRASIL, 2011, p.11)

Entretanto, para que haja eficácia na rede de atendimento às mulheres em situação de violência é necessário ampliar os canais de denúncia, capacitar os agentes públicos; padronizar esses atendimentos; aperfeiçoar constantemente a legislação; apoiar projetos educativos e culturais de prevenção à violência; ampliar o acesso das mulheres à justiça e aos serviços de segurança, punir os agressores com o rigor da Lei e o principal educar a população.

Outra questão importante é a composição da rede de proteção, esta deve ser formada por instituições governamentais, nãogovernamentais, sendo primordial a presença da sociedade buscando sempre objetivos comuns, que neste caso é cuidar dessas mulheres em situação de violência, elevando a autoestima, a valorização pessoal e financeira.

Convém lembrar que a política de isolamento social imposta, revelou-se eficaz para reduzir a contaminação causada pelo covid-19, mas mostrou o lado sombrio dessa medida, mulheres em situação de violência isoladas em casa com seus algozes se tornaram alvo fácil, dados do Estado de São Paulo desmontaram que o feminicídio aumentou de mais de $41 \%$ nesse período (FÓRUM BRASILEIRO DE SEGURANÇA PÚBLICA, 2020).

Diante dessa constatação foi necessário criar campanhas que coíbam e informem a sociedade sobre a violência doméstica, tais como a cartilha: Enfrentando a violência doméstica e familiar contra a mulher, criada pela Secretaria Nacional de Políticas para as Mulheres. É um material simples que aborda alguns temas como: "os tipos de violência, as leis de proteção, os fatores de risco e de proteção, a rede de atendimento, entre outras questões. [...] informações relevantes sobre a violência contra as mulheres nesse momento de pandemia". Mulheres (BRSIL, 2020c).

Outra ação importante em tempos de pandemia é a cartilha da campanha Sinal Vermelho contra violência doméstica, amplamente divulgada nas redes sociais, televisão, rádio e imprensa, que apresenta:

$$
\begin{aligned}
& \text { A campanha Sinal } \\
& \text { vermelho contra a } \\
& \text { violência doméstica, que } \\
& \text { permite a denúncia } \\
& \text { silenciosa. Basta um "x" } \\
& \text { vermelho, feito com } \\
& \text { batom ou qualquer outro } \\
& \text { material acessível, na } \\
& \text { palma da mão e a notícia } \\
& \text { da violência na farmácia } \\
& \text { ou drogaria cadastrada na } \\
& \text { campanha. A polícia será } \\
& \text { acionada (CNJ, 2019, p. 2). }
\end{aligned}
$$

Aguardando aprovação do Senado Federal, existe também o Projeto de Lei 1.444/20, de autoria da Deputada Alice Portugal (PCdoB-BA) que é mais uma ação importante, pois altera as Leis n.⒮ 13.979 e 13.982. Ela estabelece medidas excepcionais de proteção à mulher e a seus dependentes em situação de violência doméstica e familiar durante a pandemia do covid-19, tais como: rapidez do afastamento do agressor de sua vítima, a 
ampliação de vagas em abrigos, assegurando sigilo, segurança e acompanhamento de uma equipe multidisciplinar mulheres e outra importante medida advinda da lei é assegurar às mulheres de baixa renda em situação de violência doméstica, que estejam sob medida protetiva decretada, o direito a duas cotas do auxílio emergencial. Se aprovado terá vigência até 31 de dezembro de 2020 (BRASIL, 2020a)

As campanhas publicitárias buscam provocar de forma geral na comunidade e em especial nas próprias mulheres reflexões e ações a respeito do enfrentamento da violência, e principalmente, conscientizar todos de que a culpa não é delas. Muitas mulheres quando agredidas responsabilizam-se pela atitude dos seus agressores e quase sempre se perguntam: "O que foi que eu fiz para ele me tratar assim?"; acreditando que o seu comportamento justificasse agressões e que a violência sofrida e sua culpa e não do agressor.

Para a professora Luísa Habigzang, Coordenadora do Grupo de Pesquisa Violência, Vulnerabilidade e Intervenções Clínicas GPeVVIC, "Pedir ajuda é fundamental! Romper o silêncio é muito difícil pela vergonha, medo de ameaças ou sensação de solidão, mas é o passo inicial para proteção e garantia de direitos". (PUCRS, 2020).

As redes de proteção estão em alerta constante e divulgam nos meios de comunicação campanhas educativas e de mobilização pelo fim da violência contra mulheres, mas é fundamental que a sociedade tenha compromisso e atitude para com essas mulheres e denunciem. A violência contra mulher é um problema histórico e cultural que assola o mundo todo, inclusive o Brasil.

Análise das Medidas Protetivas do Tribunal de Justiça do Estado de São Paulo durante o covid19.

Nas lições de Távora e Alencar, as medidas protetivas de urgência previstas na Lei Maria da Penha são medidas administrativas, obrigatórias e de cunho cautelar, visando a essencialmente a proteção da mulher. Elas têm como finalidade salvaguardar a integridade física, psicológica, moral e sexual da vítima de violência doméstica (TÁVORA; ALENCAR, 2016, p. 1.260).

Por se tratar de uma medida de urgência a vítima pode solicitar para autoridade policial, ou Ministério Público, que notificará ao Juiz de Direito. A Lei prevê que autoridade judiciária deverá decidir a liminar no prazo de 48 horas após o pedido da vítima ou Ministério Público.

As medidas protetivas são meios que foram criados pela lei para prevenir a violência doméstica e familiar, visando a segurança de todas as mulheres. A Lei Maria da Penha traz dois tipos de medidas protetivas de urgência, as que obrigam o agressor a não praticar condutas ilícitas à vítima, prevista no artigo 22 e as medidas que são direcionadas à mulher e aos filhos (arts. 23 e 24 da L. 11340/2006).

Percebe-se que durante $\mathrm{o}$ isolamento social para diminuir os efeitos diretos da Covid19 , o isolamento tem tido várias consequências não apenas para a saúde, educação, economia no País, mas para a vida de milhares de mulheres que já se encontram em situação de violência doméstica.

Segundo Samira Bueno, diretoraexecutiva do Fórum Brasileiro de Segurança Pública, a pandemia de coronavírus agravou a situação de vulnerabilidade das mulheres, nos seus dizeres:

O cenário da pandemia
acentua várias das
vulnerabilidades a que as
mulheres em situação de
violência doméstica já
viviam. Uma delas é o fato
de muitas delas estarem
confinadas com os
agressores. As medidas de
isolamento social são
necessárias para o
controle da pandemia,
mas se você sofre
violência do seu
companheiro e você está
confinada em casa com
ele, isso pode se agravar.
(BUENO, 2020 apud
VIEIRA, 2020).

De acordo com a pesquisa feita no Estado de São Paulo as medidas protetivas de urgência concedidas no período de 01 à 12 Abril de 2020 comparando com o 01 à 12 de Abril de 2019 , tiveram a variação foi de - 37,9\%. (FÓRUM BRASILEIRO DE SEGURANÇA PÚBLICA, 2020).

Se analisarmos apenas os números, sem contextualizar, isso pareceria que houve uma queda porque houve uma maior conscientização por parte do agressor, mas se levarmos em conta o período de isolamento notamos que essa 
queda ocorreu de fato porque com o isolamento social, por conta do distanciamento determinado pelas autoridades, as vítimas acabaram ficando ainda mais refém de seus agressores.

Para Cavalcanti (2012), a importância das medidas protetivas contidas na Lei Maria da Penha se deve, ao fato de elas possibilitarem à vítima a solução de problemas que demandam urgência, antes do início do processo criminal.

Dias (2012, p. 147-148) destaca que existem debates sobre a natureza jurídica das medidas protetivas e afirma que elas "não são instrumentos para assegurar os processos, pois sua finalidade é impedir a continuidade da violência doméstica, portanto elas "não visão processos, mas visam pessoas", e por isso elas são tão importante.

\section{Como a educação pode mudar a cultura} patriarcal no combate a Violência Doméstica

A violência doméstica, é um tema bastante discutido, e ultimamente tem ganhado mais destaque, tanto pela mídia, como pelo próprio Estado, contudo a sociedade busca apenas a repressão deste delito.

Desde que a Lei Maria da Penha entrou em vigor, o DataSenado realiza, de 2 em 2 anos, uma pesquisa telefônica sobre o tema. De acordo com a última pesquisa realizada em 2019, 60\% das entrevistadas acreditam que aumentar a punição para os agressores seja a melhor forma de prevenção deste crime. Não que isso não seja necessário, mas em contra partida apenas 16\% entendem que discutir o tema nas escolas é a melhor forma de evitar (BRASIL, 2019).

Mostra-se com isso que é necessário uma desnaturalização da sociedade. A nossa sociedade está contaminada por um vírus chamado machismo, por meio de um código secreto e silencioso, combinado com a discriminação, molda a conduta de todos, independente de gênero, e que tem suas consequências mais visíveis na vida adulta.

Desta forma, como já dito, a educação, neste ponto, surge como uma estratégia que tem um enorme potencial para proporcionar esta mudança, haja vista que é a ferramenta mais eficaz para construir uma sociedade mais igualitária.

A educação, apesar de ser uma ferramenta excepcional, gera mudanças a longo prazo, isso porque sua finalidade é atingir toda a sociedade, não apenas um grupo isolado, por isso mudar a concepção machista mancomunada tanto nos homens como nas mulheres não é uma estratégia de fácil aplicação.

O art. 4ㅇ da "Declaração Sobre a Eliminação da Violência Contra Mulheres" trazida pela Organização das Nações Unidas (ONU) determina a importância da práxis educadora como forma de prevenção:

j) Adaptar todas as
medidas adequadas,
especialmente no domínio
da educação, a fim de
modificar os padrões de
conduta sociais e culturais
de homens e mulheres e
erradicar o preconceito,
práticas costumeiras e
outras práticas baseadas
na ideia e inferioridade ou
superioridade de qualquer
dos sexos e nos papéis
estereotipados dos
homens e das mulheres
(ASSEMBLEIA GERAL DAS
NAÇÕES UNIDAS, 1993,
n.p.)

Como realizar então essa práxis que promova essa transformação? Para Paulo Freire que somos todos seres históricos e inacabados e desta forma necessitamos da educação para nos libertarmos de manipulações ou mesmo de concepções enraizadas em nossa cultura e para que isso ocorra precisamos estar sempre em constante construção. (FREIRE, 2018b)

Quando analisamos as obras de Paulo Freire, não vemos que ele traz uma conotação explícita sobre esse tema, contudo implicitamente, ao sugerir a necessidade uma sociedade mais justa, onde todos sejam tratados de forma igual e acima de tudo quando ele nos remete a indignar-se com as injustiças, e neste caso, apontamos a Violência Doméstica, vemos que sua prática está totalmente interligada a este tema.

Isso fica mais fácil de entender quando pensamos em "oprimidos e opressores", e neste ponto vemos os homens como opressores das oprimidas mulheres. Para superar essa opressão é necessário despertar nos oprimidos uma vontade de transformar a sua realidade e, ao mesmo tempo retirar dos opressores a cultura machista e sexista, que foi enraizada em suas concepções construída ao longo das gerações, pois é preciso "restaurar a humanidade de ambos" (FREIRE, 2018b, p. 41). 
Assim, neste cenário, em busca de mudanças é que a educação aparece para viabilizar esse processo, por meio da "pedagogia do oprimido", que "busca a restauração da intersubjetividade, se apresenta como pedagogia do Homem. Somente ela, que se anima de generosidade autêntica, humanista e não 'humanitarista', pode alcançar este objetivo" (FREIRE, 2018b, p. 56).

Enquanto o atual sistema formal de educação não se comprometer em modificar, findando-se na certeza que essa realidade jamais será alterada, pois sempre foi assim, e ratificando a lógica da sociedade, as ocorrências de violência doméstica e o feminicídio jamais deixaram de existir. E o papel do educador se apresenta nesse sentido como primordial nessa mudança, pois, nas palavras de Freire (2018a) educar exige a certeza que a mudança é possível. Assim:

$$
\begin{aligned}
& \text { O mundo não é. O mundo } \\
& \text { está sendo. Como } \\
& \text { subjetividader curiosa, } \\
& \text { inteligente, interferidora } \\
& \text { na objetividade com que } \\
& \text { dialeticamenter me } \\
& \text { relaciono, meu papel no } \\
& \text { mundo não é só o de } \\
& \text { quem constata o que } \\
& \text { ocorre, mas também o de } \\
& \text { quem intervém como } \\
& \text { sujeito de ocorrências. } \\
& \text { Não sou apenas objeto da } \\
& \text { História, mas seu sujeito, } \\
& \text { igualmente. No mundo da } \\
& \text { História, da cultura, da } \\
& \text { política, constato não para } \\
& \text { me adaptar, mas para } \\
& \text { mudar (FREIRE, 2018a, } \\
& \text { p.77). }
\end{aligned}
$$

Dessarte só a educação libertadora para a igualdade constrói uma sociedade comprometida com a desnaturalização da consciência machista e patriarcal a fim de que tanto homens como mulheres entendam que são agentes de seu próprio futuro, possibilitando, desta maneira, erradicar o vírus da Violência Doméstica da nossa realidade.

\section{CONCLUSÃO}

Por meio desta pesquisa, pôde-se concluir que o afastamento social apesar de ter sido uma estratégia adotada para o enfrentamento do COVID 19 ocasionou também algumas situações preocupantes, dentre elas, o aumento da violência doméstica, haja vista, que durante esse período o agressor permaneceu por mais tempo em convívio com vítima.

Foi possível verificar portanto que, apesar do número de denúncias ter diminuído, houve, em contrapartida, um aumento no número de mortes de mulheres por feminicídio, evidenciando que, o se temia aconteceu: por estarem em convívio maior com seus agressores, houve uma maior dificuldade em denunciar, o que acabou acarretando, em vários casos, com a morte das vítimas.

Assim, podemos concluir que não basta a criação de leis punitivas mais severas, é necessário também provocar uma mudança na sociedade, em seus parâmetros, suas crenças e porque não dizer em seu comportamento.

A sociedade, apesar de se encontrar numa era moderna, tecnológica, ainda carrega conceitos antigos e preconceituosos enraizados em suas atitudes machista e como consequência disso podemos ver que o número de feminicídios continua a aumentar.

É preciso trazer mudanças, e entendemos que a educação é nossa maior aliada para que isso ocorra, mas essa educação precisa ser genuína a ponto de interferir nos comportamentos da sociedade, sendo assim, é preciso que ela seja libertadora, garantindo assim um mundo mais seguro a todas as mulheres.

\section{REFERÊNCIAS}

ASSEMBLEIA GERAL DAS NAÇÕES UNIDAS. Declaração sobre a eliminação da violência contra as mulheres. Proclamada pela Assembleia Geral das Nações Unidas na resolução 48/104, de 20 de dezembro de 1993. 1993.

ARSHAD, A.S.; BALOCH, M.; AHMED, N.; ARSHAD A.A.; IGBAL, A. The outbreak of Coronavirus Disease 2019 (COVID-19)-An emerging global health threat., J. Infect. Public. Health. Mar 18, 2020. Doi: 10.1016/j.jiph.2020.02.033.

BLAY, E. A. Feminismo e masculinidade: novos caminhos para enfrentar a violência contra a mulher. 1. ed. São Paulo: Cultura Acadêmica, 2014. Disponível em: https://apublica.org/wpcontent/uploads/2016/03/Feminismos_e_mascul inidades-WEB-travado-otimizado.pdf. Acesso em: 03 ago. 2020. 
BRASIL. [Constituição (1988)]. Constituição da República Federativa do Brasil: promulgada em 5 de outubro de 1988. 54. ed. São Paulo, 2017.

BRASIL. Presidência da República. Decreto no Decreto no 678, de 06 de novembro de 1992. Promulga a Convenção Americana sobre Direitos Humanos (Pacto de São José da Costa Rica), de 22 de novembro de 1969. Brasília: Casa Civil, 1992. Disponível em:

http://www.planalto.gov.br/ccivil_03/decreto/d0 678.htm. Acesso em: 01 ago. 2020

BRASIL. Congresso Nacional. Lei Maria da Penha. Lei n.o 11.340, de 7 de Agosto de 2006. Cria mecanismos para coibir a violência doméstica e familiar contra a mulher, nos termos do $\S 8^{\circ}$ do art. 226 da Constituição Federal, da Convenção sobre a Eliminação de Todas as Formas de Discriminação contra as Mulheres e da Convenção Interamericana para Prevenir, Punir e Erradicar a Violência contra a Mulher; dispõe sobre a criação dos Juizados de Violência Doméstica e Familiar contra a Mulher; altera o Código de Processo Penal, o Código Penal e a Lei de Execução Penal; e dá outras providências. Diário Oficial da União, Brasília, DF, 2006. Disponível em: http://www.planalto.gov.br/ccivil_03/_ato20042006/2006/lei/l11340.htm. Acesso em: 01 ago. 2020.

BRASIL. Presidência da República. Rede de Enfrentamento à Violência Contra as Mulheres. Brasília: Secretaria de Políticas para as Mulheres, 2011. Disponível em:

https://www12.senado.leg.br/institucional/omv/ entenda-a-violencia/pdfs/politica-nacional-deenfrentamento-a-violencia-contra-as-mulheres. Acesso em: 03 ago. 2020.

BRASIL. Instituto de Pesquisa DataSenado. Observatório da Mulher contra a Violência. Secretaria de Transparência. Aprofundando o Olhar sobre o Enfrentamento à Violência contra as Mulheres. Brasília: Senado Federal, 2019. Disponível em:

https://www12.senado.leg.br/institucional/datas enado/arquivos/conhecer-direitos-e-ter-rede-deapoio-sao-pontos-de-partida-para-denunciaragressao-e-interromper-ciclo-de-violencia. Acesso em: 27 jul. 2020.
BRASIL. Câmara dos Deputados. Projeto de Lei PL $\mathbf{1 4 4 4 / 2 0 2 0}$. Altera as Leis no 13.979, de 6 de fevereiro de 2020, e 13.982, de 2 de abril de 2020, para estabelecer medidas excepcionais de proteção à mulher e a seus dependentes em situação de violência doméstica e familiar durante a emergência de saúde pública de importância internacional decorrente da pandemia da Covid-19. Brasília, 2020a. Disponível em:

https://www.camara.leg.br/proposicoesWeb/fich adetramitacao idProposicao $=2242763$. Acesso em: 28 jul. 2020.

BRASIL. Ministério da Saúde. Sobre a doença. O que é o Covid -19. 2020b. Disponível em: https://coronavirus.saude.gov.br/sobre-adoenca\#o-que-e-covid. Acesso em: 03 ago. 2020.

BRASIL. Ministério da Mulher, da Família e dos Direitos Humanos. Enfrentando a violência doméstica e familiar contra a mulher. Brasília: Secretaria Nacional de Políticas para Mulheres, 2020c. Disponível em: https://www.gov.br/ebserh/pt$\mathrm{br} / \mathrm{comunicacao/noticias/ebserh-apoia-acao-do-}$ mfdh-que-visa-combater-violencia-contra-amulher/enfrentando-a-violencia-domestica-efamiliar-contra-a-mulher.pdf. Acesso em: 04 jul. 2020.

CARNEIRO, A. A.; FRAGA, C. K. A Lei Maria da Penha e a proteção legal à mulher vítima em São Borja no Rio Grande do Sul: da violência denunciada à violência silenciada. Serviço Social \& Sociedade, n. 110, p. 369-397, 2012. Disponível em:

https://www.scielo.br/scielo.php?pid=S0101$66282012000200008 \&$ script=sci_arttext\&tlng=pt Acesso em: 30 jul. 2020. DOI: https://doi.org/10.1590/S010166282012000200008 .

\section{CAVALCANTI, S. V. S. F. Violência Doméstica}

Contra a Mulher no Brasil: análise da Lei "Maria da Penha", № 11.340/06. 4. ed. Salvador: JusPODIVM, 2012. Disponível em:

https://www.editorajuspodivm.com.br/cdn/arqui vos/822 sumario.pdf. Acesso em: 30 jul. 2020.

CNJ. Conselho Nacional de Justiça. Sinal vermelho contra a violência doméstica: você não está sozinho. Brasília: Associação dos Magistrados Brasileiros, 2019. Disponível em: 
https://www.amb.com.br/wpcontent/uploads/2020/06/cartilha-sinalvermelho-AMB-6.pdf. Acesso em: 28 de julho de 2020.

DIAS, M. B. A Lei Maria da Penha na Justiça: a efetividade da Lei 11.340/2006 de combate à violência doméstica e familiar contra a mulher. 3. ed. São Paulo: Editora Revista dos Tribunais, 2012.

DUARTE, L. Mortes por Covid-19 no Brasil podem chegar a $\mathbf{1 2 5}$ mil até agosto, diz estudo. CNN Brasil, 26 de maio de 2020, 2020. Disponível em: https://www.cnnbrasil.com.br/saude/2020/05/2 6/mortes-por-covid-19-no-brasil-podem-chegara-125-mil-ate-agosto-diz-estudo. Acesso: 09 de julho de 2020.

FÓRUM BRASILEIRO DE SEGURANÇA PUBLICA. Visível e Invisível: a vitimização de mulheres no Brasil. 2. ed. São Paulo, 2019. Disponível em: http://www.iff.fiocruz.br/pdf/relatorio-pesquisa2019-v6.pdf. Acesso em: 21 jul. 2020.

\section{FÓRUM BRASILEIRO DE SEGURANÇA PÚBLICA.} Violência doméstica durante a pandemia de covid-19. 2. ed. São Paulo, 2020. Disponível em: https://forumseguranca.org.br/publicacoesposts/violencia-domestica-durante-pandemia-decovid-19-edicao-02/. Acesso em 21 de julho de 2020 .

FREIRE, P. Pedagogia da autonomia: saberes necessários a prática educativa. 56 . ed. Rio de Janeiro: Paz e Terra, 2018a.

FREIRE, P. Pedagogia do oprimido. 65. ed. Rio de Janeiro: Paz e Terra, 2018b.

GOMES, C. M. Marcas da violência contra a mulher na literatura. Revista Diadorim - Revista de Estudos Linguísticos e Literários do Programa de Pós-Graduação em Letras Vernáculas da Universidade Federal do Rio de Janeiro, Rio de Janeiro, v. 13, jul. 2013. https://revistas.ufrj.br/index.php/diadorim/articl e/view/3981 - Acesso em: 25 jul. 2020. DOI: https://doi.org/10.35520/diadorim.2013.v13n0a3 $\underline{981 .}$

IHME. Projeções COVID-19, 2020. Disponível em: https://covid19.healthdata.org/brazil. Acesso em: 08 jul. 2020.
IMP. Instituto Maria da Penha. Ciclo da Violência: Saiba identificar as três principais fases do ciclo e entenda como ele funciona. Fortaleza, 2009. Disponível em:

https://www.institutomariadapenha.org.br/viole ncia-domestica/ciclo-da-violencia.html. Acesso em 12 de julho de 2020 .

INSTITUTO DE PESQUISA ECONÔMICA APLICADA. Fórum Brasileiro de Segurança Pública. ATLAS DA VIOLÊNCIA 2019. São Paulo, 2019. Disponível em: https://forumseguranca.org.br/wpcontent/uploads/2019/06/Atlas-da-Violencia2019_05jun_vers\%C3\%A3o-coletiva.pdf. Acesso em 5 de jul. 2020.

INSTITUTO IGARAPÉ. EVA. Evidências sobre Violência e Alternativas para Mulheres e Meninas. 2019. Disponível em: https://eva.igarape.org.br/. Acesso em: 03 ago. 2020.

JONES, D.S. History in a Crisis - Lessons for COVID-19. N. EngL. J. Med. March 12, 2020.

LIMA, C. M. O caso Maria da Penha no Direito Internacional. A pressão externa fomentando mudanças em uma nação. Revista Jus Navigandi, Teresina, v. 23, n. 5369, 14 mar. 2018. Disponível em: https://jus.com.br/artigos/58908. Acesso em: 31 jun. 2020.

OPAS Brasil. ORGANIZAÇÃO PAN-AMERICANA DA SAÚDE. Organização Mundial da Saúde. Brasil confirma primeiro caso de infecção pelo novo coronavírus. OPAS/OMS Brasil, 2020. Disponível em:

https://www.paho.org/bra/index.php?option=co m_content\&view=article\&id=6113:brasilconfirma-primeiro-caso-de-infeccao-pelo-novocoronavirus\&Itemid=812. Acesso em: 09 jul. 2020.

PUCRS. Pontifícia Universidade Católica do Rio Grande Cartilha aborda consequências do isolamento e a violência doméstica. Porto Alegre, 2020. Disponível em: http://www.pucrs.br/blog/cartilha-abordaconsequencias-do-isolamento-e-a-violenciadomestica/. Acesso em: 04 ago. 2020.

SANTIAGO, R. A. A violência contra a mulher: antecedentes históricos. Seminário Estudantil de Produção Acadêmica, Salvador, v. 11, n. 1, 2007. 
Disponível em:

https://revistas.unifacs.br/index.php/sepa/article

/view/313. Acesso em: 15 jul. 2020.

SANTOS, B. S. Reconhecer para libertar: os

caminhos do cosmopolitismo multicultural. Rio

de Janeiro: Civilização Brasileira, 2003.

SILVA, S. G. Preconceito e discriminação: as bases da violência contra a mulher. Psicologia: ciência e profissão, v. 30, n. 3, p. 556-571, 2010. Disponível em:

https://www.scielo.br/scielo.php?pid=S141498932010000300009\&script=sci_arttext. Acesso em 03 ago. 2020. https://doi.org/10.1590/S1414$\underline{9832010000300009 .}$.

TÁVORA, N.; ALENCAR, R. R. Curso de direito processual penal. 11. ed. Bahia: Jus Podivm, 2016.

TOKARSKI , C. P. ; ALVES, I. Covid 19 e Violência Doméstica: pandemia dupla para as mulheres. ANESP, 5 abr. 2020. Disponível em: http://anesp.org.br/todas-asnoticias/2020/4/6/covid-19-e-violncia-domsticapandemia-dupla-para-as-mulheres. Acesso em: 03 ago. 2020.

VALENTÍN E.D.L.; MONTERO J.S.N.; FLORENTINI, M.G.Q. Coronavirus causante del síndrome respiratorio de Oriente Medio (MERSCoV). Revista Médica Carriónica, v.1, n. 1: I, 2019

VIEIRA, B. M. Casos de feminicídio crescem $41,4 \%$ em SP durante pandemia de Covid-19, diz estudo. G1, São Paulo, 02 jun. 2020. Disponível em: https://g1.globo.com/sp/saopaulo/noticia/2020/06/02/casos-de-feminicidiocrescem-414percent-em-sp-durante-pandemiade-covid-19-diz-estudo.ghtml. Acesso em: 14 jul. 2020. 